\title{
The Effect of Nutritional Additives and Nitrogen Supplements Used for Nellore Steers During Growth Phase Fed on Deferred Pasture
}

\author{
Luis Carlos Vinhas Itavo (Corresponding author)
}

Faculdade de Medicina Veterinária e Zootecnia, Universidade Federal de Mato Grosso do Sul. Av. Senador Filinto Muller, 2443. Vila Ipiranga. 79070-900. Cidade Universitária, Campo Grande, Mato Grosso do Sul, Brasil. E-mail: luis.itavo@ufms.br

\section{Camila Celeste Brandão Ferreira Itavo}

Faculdade de Medicina Veterinária e Zootecnia, Universidade Federal de Mato Grosso do Sul. Av. Senador Filinto Muller, 2443. Vila Ipiranga. 79070-900. Cidade Universitária, Campo Grande, Mato Grosso do Sul, Brasil.E-mail: camila.itavo@ufms.br

\section{Alexandre Menezes Dias}

Faculdade de Medicina Veterinária e Zootecnia, Universidade Federal de Mato Grosso do Sul. Av. Senador Filinto Muller, 2443. Vila Ipiranga. 79070-900. Cidade Universitária, Campo Grande, Mato Grosso do Sul, Brasil. E-mail: alexandre.menezes@ufms.br

\section{Gumercindo Loriano Franco}

Faculdade de Medicina Veterinária e Zootecnia, Universidade Federal de Mato Grosso do Sul. Av. Senador Filinto Muller, 2443. Vila Ipiranga. 79070-900. Cidade Universitária,

Campo Grande, Mato Grosso do Sul, Brasil. E-mail: gumercindo.franco@ufms.br

\section{Maria da Graça Morais}

Faculdade de Medicina Veterinária e Zootecnia, Universidade Federal de Mato Grosso do Sul. Av. Senador Filinto Muller, 2443. Vila Ipiranga. 79070-900. Cidade Universitária,

Campo Grande, Mato Grosso do Sul, Brasil. E-mail: morais.mariazinha@gmail.com 


\title{
Macrothink

Universidade Estadual de Mato Grosso do Sul, Unidade Aquidauana. Rodovia Aquidauana-CERA, Km 13. Zona Rural. 79200000 - Aquidauana, Mato Grosso do Sul, Brazil. E-mail: andrea.souza@uems.br

\section{Camila da Silva Pereira}

Faculdade de Medicina Veterinária e Zootecnia, Universidade Federal de Mato Grosso do Sul. Av. Senador Filinto Muller, 2443. Vila Ipiranga. 79070-900. Cidade Universitária, Campo Grande, Mato Grosso do Sul, Brasil. E-mail: camila.silvapereira@ hotmail.com

\section{Alexandre Guimarães Inacio}

Faculdade de Medicina Veterinária e Zootecnia, Universidade Federal de Mato Grosso do Sul. Av. Senador Filinto Muller, 2443. Vila Ipiranga. 79070-900. Cidade Universitária,

Campo Grande, Mato Grosso do Sul, Brasil. E-mail: alexandreg.inacio@gmail.com

\section{Rodrigo Gonçalves Mateus}

${ }^{2}$ Universidade Católica Dom Bosco, Campo Grande, Brazil, Av. Tamandaré, 6000 - Jardim Seminário, 79117-900, Campo Grande, Mato Grosso do Sul, Brasil. E-mail: rf4789@ucdb.br

\section{Luiz Carlos Pereira}

${ }^{2}$ Universidade Católica Dom Bosco, Campo Grande, Brazil, Av. Tamandaré, 6000 - Jardim Seminário, C.P. 79106-550, Campo Grande, Mato Grosso do Sul, Brasil. E-mail: luizcp.agro@gmail.com

Received: May 5, 2020

doi:10.5296/jas.v8i2.17226
Accepted: June 16, 2020 Published: June 22, 2020

URL: https://doi.org/10.5296/jas.v8i2.17226

\begin{abstract}
Dry season reduces the quantity and quality of forage available for cattle. To guarantee the quantity, deferred grazing is a good alternative, however supplementation is necessary to complement the nutritional quality of the diet. Therefore, this work evaluated the inclusion of nutritional additives (virginiamycin and salinomycin) in supplements provide to Nellore steers during growth phase on deferred pasture during the dry season. One hundred and twenty castrated steers with averaging weight $280.40( \pm 19.59) \mathrm{kg}$ were distributed into groups with 20 animals each in six paddocks with 20 hectares each of Brachiaria brizantha
\end{abstract}


cv. MG4 deferred by 60 days. The total experimental period was 120 days, with rotating groups in paddocks each 15 days. The treatments consisted in a protein-energy-mineral supplement, with $30 \%$ crude protein (CP), $40 \%$ total digestible nutrient (TDN) containing three different non-protein nitrogen (NPN) sources and with or without nutritional additive. The treatment containing virginiamycin showed better performance $(\mathrm{P}<0.05)$ than the treatments with salinomycin and without additive (negative control). The revenue from treatment with virginiamycin (US\$ 97.28) was 7.6\% and 9.8\% higher than of the treatments without additive (US\$ 90.41) and with salinomycin (US\$ 88.63) respectively. Virginiamycin used in nitrogen supplements during the growing phase of Nellore steers on deferred pasture maintains performance in dry season and increases net margin per animal.

Keywords: forage, supplementation, urea, salinomycin, virginiamycin

\section{Introduction}

The climate in central Brazil (Brazilian Cerrado) stands out for long dry periods overlapping with winter season; consequently, there is less quantity and quality of the forage available, with higher amount of structural carbohydrates, lower crude protein content, and a decrease in forage nutritive value (Silva et al., 2009). Forage is the basis of cattle feeding, and nutrient availability depends on pasture biomass (Prohmann et al., 2012a). In autumn and winter, the forage availability could be guaranteed through deferred grazing, however, it is necessary to intervene with supplementary nutrients to meet nutritional requirements (Zervoudakis et al. 2008).

Supplementation has been used to improve the performance of animals, providing greater production system efficiency. Therefore, the use of deferred pastures should be associated with dietary supplementation (Silva et al., 2009). Thus, is recommended offering $20 \mathrm{~kg}$ DM (dry matter) of forage by $100 \mathrm{~kg}$ body weight in deferrals pasture systems (Schio et al., 2011). Some experiments (Ítavo et al., 2007a; 2007b) also advised protein-energetic supplements with $40 \%$ crude protein for cattle in deferred pastures during the dry period of the year (June to September in Brazil).

Assessing the nutritional value of deferred pastures of Brachiaria decumbens and Brachiaria brizantha it was verified that crude protein and energy contents of these pastures were limiting factors to animal production (Euclides et al., 2001). The goals as well as the economic results should be considered when choosing a supplementation strategy (Lima et al., 2012). Therefore, it is important to assess market prices before choosing the supplementation strategy (Prohmann et al., 2012b).

The manipulation of ruminal fermentation seeks to increase the synthesis of propionic acid, decrease methane production and proteolysis in the rumen. Some nutritional additives, such as ionophores, can increase food efficiency. Ionophores are organic compounds capable of modifying the ruminal fermentation profile, interacting passively with cations $(\mathrm{K}+, \mathrm{Na}+$, $\mathrm{Ca} 2+$ and $\mathrm{Mg} 2+$ ), been transport through cell membranes (Rangel et al., 2008).

Thus, the objective of this study was to evaluate the inclusion of nutritional additives (virginiamycin or salinomycin) on concentrate supplements for Nellore steers in deferred 
pastures of Brachiaria brizantha cv. MG4, during the dry season, observing the aspects of production and economic performance.

\section{Material and Methods}

The study was conducted at central Brazil (Coordinates $19.48^{\circ} \mathrm{S}, 54,11^{\circ} \mathrm{W}$ ), average annual rain fall is $1235 \mathrm{~mm}$, annual temperature ranges between $2^{\circ} \mathrm{C}$ and $30^{\circ} \mathrm{C}$.

One hundred and twenty Nellore castrated steers with averaging $280.40( \pm 19.59) \mathrm{kg}$ were distributed into groups with 20 animals each in six paddocks with 20 hectares each of Brachiaria brizantha cv. MG4 deferred by 60 days.

Before the experiment all animals were weighed, identified, tracked and subjected to the control of ectoparasites and endoparasites (Ludke et al., 2012). The animals were raised according to the guidelines of the Ethics, Bioethics and Animal Welfare Committee of the Brazilian Council of Veterinary Medicine (CFMV, 2014).

The treatments (Table 1) consisted of a concentrate supplement, with protein $(30 \% \mathrm{CP})$, energy (40\% TDN), minerals and three different non-protein nitrogen (NPN) sources (Urea free urea source, Starea-200S - extruded urea source and Optigen ${ }^{\circledR}$ - protected urea source), with or without addition of $200 \mathrm{mg}$ of additive (Salinomycin sodium or Virginiamycin) per $\mathrm{kg}$ of supplement.

Table 1. Experimental trials ingredients

\begin{tabular}{lccc}
\hline & No additive & Virginiamycin & Salinomycin \\
\hline Cottonseed meal $(\mathrm{g} / \mathrm{kg})$ & 357.15 & 357.15 & 357.15 \\
Mineral $(\mathrm{g} / \mathrm{kg})^{\#}$ & 559.45 & 559.45 & 559.45 \\
Starea-200 $(\mathrm{g} / \mathrm{kg})$ & 33.34 & 33.34 & 33.34 \\
Optigen $\mathrm{g} / \mathrm{kg})$ & 26.25 & 26.25 & 26.25 \\
Urea g/kg) & 23.81 & 23.81 & 23.81 \\
Additive $(\mathrm{mg} / \mathrm{kg})$ & - & 200 & 200 \\
\hline
\end{tabular}

Starea-200S (Pajoara Ind. e Comércio Ltda., Campo Grande, Brazil); Optigen ${ }^{\circledR}$ (Alltech); ${ }^{\#}$ Mineral $(\mathrm{Ca}=40 \mathrm{~g} / \mathrm{kg} ; \mathrm{P}=22 \mathrm{~g} / \mathrm{kg} ; \mathrm{Na}=44 \mathrm{~g} / \mathrm{kg} ; \mathrm{S}=12 \mathrm{~g} / \mathrm{kg} ; \mathrm{Co}=20 \mathrm{mg} / \mathrm{kg} ; \mathrm{Cu}=500$ $\mathrm{mg} / \mathrm{kg} ; \mathrm{I}=30 \mathrm{mg} / \mathrm{kg} ; \mathrm{Mn}=3000 \mathrm{mg} / \mathrm{kg} ; \mathrm{Se}=10 \mathrm{mg} / \mathrm{kg} ; \mathrm{Zn}=1500 \mathrm{mg} / \mathrm{kg}$ ).

The experimental design was randomized blocks by body weight with three treatments and 40 replicates per treatment. The animals were organized into six groups, with two groups with 20 animals each per treatment, totaling 120 animals in six paddocks. The weighing of the animals was performed every 30 days. The steers were re-allocated in paddocks different from the one in which they were to guarantee the withdrawal of the paddock effect on the supplement consumption and performance of the animals.

All supplements were formulated to contain cottonseed meal, suppling 1/3 of the total CP. The remaining of protein, up to $30 \%$, was supplied by the inclusion of different sources of NPN being urea, extruded urea (Starea-200S® - Amireia Pajoara Ind. and Comércio Ltda., Campo Grande, Brazil) and protected urea (Optigen ${ }^{\circledR}$ Alltech).

The consumption of supplement was weekly quantified through the information of the 
quantities offered and leftovers. At the end of the experimental period (120 days), the costs and net margins by animal and treatments were evaluated using local market prices (Table 2).

To determine the availability, forage was sampled from the paddocks 60 days after deferral, prior to the entrance of animals. In each paddock, samples were collected with a square of 1.0 $\mathrm{m}^{2}$, five centimeters from the soil. Subsequently the samples were separated in green material (leaf plus stem) and dead material. After separation, the samples were identified and then heated to $65^{\circ} \mathrm{C}$ for 72 hours. After pre-drying, samples were weighed and milled so that the laboratory analyses were carried out (Detmann et al., 2012).

Table 2 - Supplements costs

\begin{tabular}{llll}
\hline & No additive & Virginiamycin & Salinomycin \\
\hline Cost (US\$/bag with 30 kg) & 15.07 & 18.40 & 15.33 \\
\hline Cost (US\$/kg) & 0.50 & 0.61 & 0.51 \\
\hline
\end{tabular}

For the economic evaluation, the average daily gain information was transformed into arrobas. Carcass gain $=$ Total Gain $\times 0.52 / 15$, was then taken into account, and then the arroba value: Revenue/animal $=$ Carcass gain $(@ /$ animal $) \times$ US\$ 54.22.

Net revenue margin $($ US\$/animal $)=$ Revenue - Total cost with supplement by animal;

Net Margin (US\$/kg gained) = Net Margin/animal/120 days/Daily gain;

Net Margin = Net Margin/Gain of Carcass.

All data were submitted to analysis of variance (Statistical Analysis Systems - SAS, version 9.1, SAS Institute, Inc. Cary, NC, USA) using PROC MIXED according to a randomized design with three treatments.

Equation 1 (Eq.1) shows the statistical model used:

$$
Y i j=\mu+\mathrm{Ai}+\text { eij }
$$

Where: $\mu$ is the general average; $\mathrm{A} i$ is the effect of the $\mathrm{i}$-th additive $(1, \ldots, 3)$; and eij is the random error.

We used the initial weight as covariant to analyzing all data. For all the variables, p-values less than or equal to 0.05 were declared significant and values than or equal to 0.10 were considered tendencies.

\section{Results and Discussion}

Initially, the pasture showed an average availability of green forage of $4.5 \mathrm{t} \mathrm{DM} / \mathrm{ha}$ (Table 3), with $69.5 \%$ in vitro digestibility of DM (IVDDM), 10.6\% CP and $63.9 \%$ neutral detergent fiber (NDF). After 120 days of pasturing, end of experimental period, the availability of green matter was far below what is necessary to maintain a suitable performance for steers in the growth phase.

Pastures with less than $2.0 \mathrm{t} \mathrm{DM} / \mathrm{ha}$ result in lower pasture consumption and increased 
grazing time, negatively influencing animal performance (Minson, 1990; NRC, 2000). At the end of the period, there was a high amount of dead material with low $\mathrm{CP}$ content, consequently low IVDDM (55\%) and high fiber content, both in the green material $(66.3 \%$ $\mathrm{NDF}$ ) and in the dead (78\% NDF). During the period of growth in the deferment, there is accumulation of dead material, associated to the natural aging of the plant (Schio et al., 2011). It is also observed an increase in the proportion of dead matter in relation to the green, resulting in lower quality of available forage. Brachiaria brizantha and B. decumbens in the dry period presented high levels of NDF (60.4 to 86.7\%), low CP (2.3 to 10.1\%) and low IVDDM (42 to $60.6 \%$ ) (Ítavo et al., 2013).

Table 3. Pasture characteristics of de Brachiaria brizantha cv. MG4. 60 days deferred, by period of sampling

\begin{tabular}{|c|c|c|c|c|}
\hline & Total Mass (kg MS/hectare) & $\mathrm{CP}$ & NDF & DIVMS \\
\hline \multicolumn{5}{|c|}{ Green Material } \\
\hline July & 4554,49 & 10.95 & 65.86 & 71.57 \\
\hline August & 2596.47 & 9.42 & 68.67 & 56.02 \\
\hline September & 1590.25 & 6.64 & 67.94 & 55.88 \\
\hline October & 950.82 & 6.40 & 67.28 & 54.68 \\
\hline \multicolumn{5}{|c|}{ Dead Material } \\
\hline July & 3298,69 & 4.02 & 75.73 & 43.27 \\
\hline August & 2250.15 & 3.77 & 73.49 & 38.21 \\
\hline September & 1634.60 & 2.88 & 74.91 & 35.89 \\
\hline October & 1282.06 & 2.56 & 76.44 & 32.42 \\
\hline
\end{tabular}

Nitrogen supplements with Virginiamycin presented superior performance $(\mathrm{P}<0.05)$ to other treatments (no nutritional additive and Salinomycin) (Table 4). The average daily gain of Virginiamycin treatment was $0.43 \mathrm{~kg} /$ day, higher than the $0.40 \mathrm{~kg} /$ day Salinomycin treatment and the treatment without nutritional additive. This performance allowed a carcass gain of 1.79 arrobas, while the treatments without nutritional additive and Salinomycin presented 1.67 and 1.63 arrobas/animal, respectively.

A better weight gain can be observed in the treatment with viginimicina, which showed superiority both to treatment without nutritional additive and to treatment with salinomycin. Even in small amounts $(200 \mathrm{mg} / \mathrm{kg})$, the inclusion of virginiamycin was favorable to growth performance. Probably there was reduction in methane synthesis due to the action of Virginiamycin on the membrane of the Gram-positive bacteria that facilitates the bacteriostatic action of the product. However, the same did not occur with Salinomycin.

The performance of nutritional additives (ionophores and antimicrobials) in the performance of animals is a result of the improvement in the efficiency of energy metabolism. This is because there is a change in the volatile fatty acids produced in the rumen (increase in propionate, reduction in acetate and butyrate), and decrease in the energy lost during the fermentation of nutrients. The best animal performance of the Virginiamycin treatment is likely to be a result from increased energy retention during ruminal fermentation. Ionophores foment the growth of Gram-negative bacteria, propionate-producing bacteria, favoring the fermentative pattern and energy production from the diet (Rangel et al., 2008). 
Table 4. Effect of the inclusion of nutritional additives on nitrogenate supplements under the productive performance of steers kept in Brachiaria brizantha cv. MG4 pasture

\begin{tabular}{llll}
\hline \multirow{2}{*}{ Variables } & \multicolumn{2}{l}{ Trials $^{\#}$} & \\
\cline { 2 - 4 } & No additive & Salinomycin & Virginiamycin \\
\hline Initial BW (kg) & $280.50 \mathrm{a}$ & $280.55 \mathrm{a}$ & $280.35 \mathrm{a}$ \\
Final BW (kg) & $328.60 \mathrm{~b}$ & $328.70 \mathrm{~b}$ & $332.10 \mathrm{a}$ \\
Total weight gain (kg/animal) & $48.10 \mathrm{~b}$ & $48.15 \mathrm{~b}$ & $51.75 \mathrm{a}$ \\
Daily weight gain (DWG) (kg/day) & $0.40 \mathrm{~b}$ & $0.40 \mathrm{~b}$ & $0.43 \mathrm{a}$ \\
DWG July & $1.08 \mathrm{a}$ & $1.04 \mathrm{a}$ & $0.98 \mathrm{~b}$ \\
DWG August & $0.64 \mathrm{a}$ & $0.59 \mathrm{~b}$ & $0.41 \mathrm{c}$ \\
DWG September & $-0.07 \mathrm{c}$ & $0.27 \mathrm{~b}$ & $0.49 \mathrm{a}$ \\
DWG October & $-0.05 \mathrm{a}$ & $-0.29 \mathrm{c}$ & $-0.13 \mathrm{~b}$ \\
Carcass gain (@/animal) * & $1.67 \mathrm{~b}$ & $1.63 \mathrm{~b}$ & $1.79 \mathrm{a}$ \\
\hline
\end{tabular}

\#Means followed by lower case letters at the same line differ from one another by the Tukey test $(\mathrm{P}<0.05)$. *Gain of carcass $(@ /$ animal $)=$ Total gain $\mathrm{x} 0.52 / 15$

The results of performance (Table 4) and supplement consumption (Table 5) are in accordance with the literature reports (Nagaraja et al., 1997) who mentioned that ionophores do not decrease food intake, but improve body weight gain, increase efficiency of energy metabolism and alter the metabolism of nitrogen in the rumen. However, only Virginiamycin treatment was able to promote improvement in body weight gain. Supplements without nutritional additive or Salinomycin were still able to maintain good performance for the animals kept in the deferred pastures. Probably due to the supply of proteins and NPN included in the treatments (Table 1), since the pastures showed a drastic reduction in the CP content (Table 3) over the dry period.

The financial feedback per animal, was obtained by means of the carcass gain and the commercial value of the arroba (US\$ 54.22). It is observed that animals receiving Virginiamycin treatment had an average of US\$ 97.28 (Table 5). This value is higher by $7.6 \%$ and $9.8 \%$, respectively than those obtained by treatment without nutritional additive (US\$ 90.41) and Salinomycin treatment (US\$ 88.63).

There was effect of the inclusion of nutritional additive on supplement intake $(\mathrm{P}<0.05)$, with averages of 0.41 and $0.42 \mathrm{~kg} / \mathrm{day}$, respectively, for Salinomycin and Virginiamycin treatments. The treatment without nutritional additive had a mean intake of supplement $(0.45 \mathrm{~kg} / \mathrm{day})$, $9 \%$ higher than treatments with nutritional additive (Salinomycin or Virginiamycin). This fact represents an important economy of scale for the growth stage, which requires supplementation of steers to obtain favorable performance (Table 5).

Because of the difference in supplement intake, there was effect $(\mathrm{P}<0.05)$ of treatment on supplementation costs (Table 5). Salinomycin treatment had the lowest costs of gain (US\$ 0.53/kg gain), daily cost (US\$ 0.21) and total cost with supplement (US\$ 25.15/animal). These results demonstrate the effect of the nutritional additive on reducing consumption, improving feed conversion and/or improving performance (Table 5). 
Table 5. Effect of nutritional additive inclusion on nitrogenate supplements under the aspects of intake and economic performance of steers kept on Brachiaria brizantha cv. MG4 pasture

\begin{tabular}{llll}
\hline \multirow{2}{*}{ Variables } & \multicolumn{3}{l}{ Trials $^{\#}$} \\
\cline { 2 - 4 } & No additive & Salinomycin & Virginiamycin \\
\hline Revenue (US\$/animal) & $90.41 \mathrm{~b}$ & $88.63 \mathrm{~b}$ & $97.28 \mathrm{a}$ \\
\hline Supplement intake (kg/day) & $0.45 \mathrm{a}$ & $0.41 \mathrm{~b}$ & $0.42 \mathrm{~b}$ \\
Total intake (kg/animal) & $54.24 \mathrm{a}$ & $49.20 \mathrm{c}$ & $50.50 \mathrm{~b}$ \\
\hline Cost of gain (US\$/kg PV gain) & $0.56 \mathrm{~b}$ & $0.53 \mathrm{c}$ & $0.60 \mathrm{a}$ \\
Daily cost with supplement (US\$/day) & $0.23 \mathrm{~b}$ & $0.21 \mathrm{c}$ & $0.26 \mathrm{a}$ \\
Total cost with supplement (US\$/animal) & $27.24 \mathrm{~b}$ & $25.15 \mathrm{c}$ & $30.97 \mathrm{a}$ \\
\hline Net margin (US\$/animal) & $63.17 \mathrm{~b}$ & $63.48 \mathrm{~b}$ & $66.30 \mathrm{a}$ \\
Net margin (US\$/kg BW gain) & $1.32 \mathrm{~b}$ & $1.35 \mathrm{a}$ & $1.28 \mathrm{c}$ \\
Net margin (US\$/@ produced) & $37.88 \mathrm{~b}$ & $38.82 \mathrm{a}$ & $36.96 \mathrm{c}$ \\
\hline
\end{tabular}

Means followed by lowercase letters on the same line differ from each other by the Tukey test $(\mathrm{P}<0.05)$

1 Revenue $($ US $\$$ /animal $)=$ Carcass gain $(@ /$ animal $) \times$ US\$ 54.22

2 Net margin (US\$/animal) = Revenue (US\$/animal) - Total cost with supplement (US\$/animal)

3 Net margin $($ US\$ $/ \mathrm{kg}$ gain $)=$ Net margin $($ US\$/animal $) / 120$ days $/$ Daily gain $(\mathrm{kg} /$ day $)$

4 Net margin (US\$/@ produced)= Net margin (US\$/animal)/ Carcass gains (@/animal)

The daily cost of Virginiamycin treatment (US\$ 0.26) was higher than the Salinomycin treatment (US\$ 0.21). Such superiority represents $23 \%$ over the total costs with supplements containing Salinomycin and $13 \%$ over the supplement without nutritional additive. It is observed that Virginiamycin treatment presented the highest net margin per animal (US\$ 66.30/animal). This fact demonstrates its positive effect on productive performance in the growth stage. However, no differences were detected between treatments Salinomycin and treatment without additive for net margin per $\mathrm{kg}$ gain and per arroba produced.

For short-cycle animals, weight loss during growth does not allow slaughter in less than 30 months. Nellore steers that received only mineral salt were only slaughtered at 36 months of age (Euclides et al., 2001). The increase in supplementation with multiple mixtures in Brachiaria brizantha pastures promotes increases in consumption and performance when compared to mineral supplementation (Silva et al., 2009).

Considering that NPN sources are extensively degraded in the rumen (Ítavo et al. 2016), probably the rate at which energy is available is the most limiting factor for microbial synthesis (Valadares et al., 2010; Santos et al., 2016), since fibrous carbohydrates present a slow rate of degradation. Thus, the supply of moderate amounts of non-fibrous carbohydrates present in the supplement probably provided an increase microbial $\mathrm{N}$ flow to the abomasum due to its average solubilization rate in the ruminal environment (Valadares et al., 2010; Ítavo et al., 2016; Santos et al., 2016).

When the goal of supplementation is to achieve gains of up to $0.5 \mathrm{~kg} / \mathrm{day}$, there is a need to include energy and protein in the supplement (Silva et al., 2009). There is some supplementation recommendation during the dry period and the consumption may vary from $0.1 \%$ to $0.6 \%$ of body weight, depending on the expected objective (NRC, 2000). 
A study was carried out with steers supplemented in Brachiaria brizantha pastures receiving mineral mixture, mineral plus urea, sulfur and corn, and mineral plus starea (Ítavo et al., 2008). Nutritional treatments were as follow: MS - mineralized salt only; ST -mineralized salt plus starea - 150S; and UR - mineralized salt plus urea, corn and sulphur. UR supplement was prepared mixing the same ingredient contents of starea treatment. Crossbred steers consumed 206.1; 145.9 and 73.1g/day whereas Nellore steers consumed 236.0; 205.11 and $94.29 \mathrm{~g} /$ day of ST, UR and MS; respectively. For Nellore steers, UR increased slaughter weight (518.8kg) compared to ST and MS (491.9 and $485.2 \mathrm{~kg}$, respectively). Protein supplementation also increased slaughter weight for crossbred steers $(\mathrm{P}<0.05)$ in comparison to animals fed mineralized salt as sole supplementation $(515.9$ and $520.2 \mathrm{~kg}$ for the UR and ST, respectively). Ítavo et al. (2008) concluded NPN supplementation enhances growing performance of crossbred steers during periods of forage abundance.

Supplements with NPN sources with medium-slow solubility characteristics (Starea and Optigen) in the ruminal environment provide better performance and consequently better economic results. One of the predominant factors regarding the production of animals in a pasture supplementation system is the definition of supplementation. Consequently, supplementation strategies must be established to enable established growth patterns (Mateus et al., 2011). Thus, supplement economic value, consumption and performance are determining factors for the success of supplementation of steers in the growth stage.

\section{Conclusion}

The use of virginiamycin in supplements during the growth stage of steers on deferred pastures maintains performance and increases the net margin per animal. Salinomycin did not have a significantly effect when compared to the control group (without additives). The inclusion of sources of NPN can favor the productive performance of steers in the growth stage in deferred pastures and when combined with Virginiamycin this effect can be improved.

\section{Acknowledgements}

The authors thank Federal University of Mato Grosso do Sul (UFMS), Catholic University Dom Bosco (UCDB), Conselho Nacional de Desenvolvimento Científico (CNPq) e Tecnológico, Fundação de Apoio ao Desenvolvimento do Ensino, Ciência e Tecnologia do Estado de Mato Grosso do Sul (FUDECT). This study was financed in part by the Coordenação de Aperfeiçoamento de Pessoal de Nível Superior - Brasil (CAPES) - Finance Code 001.

\section{References}

Conselho Federal de Medicina Veterinária-. CFMV. (2014). Guia brasileiro de boas práticas $\begin{array}{lllll}\text { para a } & \text { eutanásia } & \text { de } & \text { animais. } & 2014 .\end{array}$ http://www.cfmv.gov.br/portal/_doc/guiabbp_eutan\%C3\%A1sia_animal.pdf

Detmann, E., Souza, M. A., Valadares-Filho, S. C., Queiroz, A. C., Berchielli, T. T., Saliba, E. O. S., et al. (2012). Métodos para Análise de Alimentos - INCT - Ciência Animal. ${ }^{\text {rst }}$ ed. 
Visconde do Rio Branco, MG, Brazil: Suprema; 2012. 214p.

Euclides, V. P. B., Euclides-Filho, K., Costa, P. P., \& Figueiredo, G. R. (2001). Performance of F1s Angus-Nellore Steers on Brachiaria decumbens Pasture Under Different Feeding Regimes. Revista Brasileira de Zootecnia, 30(2), 470-481. https://doi.org/10.1590/S1516-35982001000200025

Ítavo, L. C. V., Dias, A. M., Andreson, H. C., \& Ítavo, C. C. B. F. (2007b). Productive performance and economic evaluation of steers supplemented in the dry period in differed pastures, under two stoking rates. Revista Brasileira de Saúde e Produção Animal, 8(4), 309-316. http://revistas.ufba.br/index.php/rbspa/article/view/791/530

Ítavo, L. C. V., Ítavo, C. C. B. F., Dias, A. M., Franco, G. L., Pereira, L. C., Leal, E. S., ... Souza, A. R. D. L. (2016). Combinations of non-protein nitrogen sources in supplements for Nellore steers grazing. Revista Brasileira de Saúde e Produção Animal, 17(3), 448-460. https://doi.org/10.1590/S1519-99402016000300011

Ítavo, L. C. V., Silva, F. F., Schio, A. R., Ítavo, C. C. B. F., Dias, A. M., Nogueira, E., ... Kaveski, M. S. (2013). Suplementação a pasto: Estratégias nutricionais. In: Barbosa, M.A.A.F., Cecato, U., Galbeiro, S., Miorin, R.L., Saad, R.M., Brito, V.C., Gonçalves, J.R.S. (edsO. Simpósio De Produção Animal A Pasto, 2. Stampha, Maringa, PR. 2013. pp.199-242.

Ítavo, L. C. V., Tolentino, T. C. P., Ítavo, C. C. B. F., Euclides Filho, K., Morais, M. G., Silva, F. F., ... Siva, J. P. B. (2008). Productive performance, carcass characteristics and economic evaluation of castrated and non-castrated crossbred bovines finished in Brachiaria decumbens pastures. Arquivo Brasileiro Medicina Veterinária e Zootecnia, 60(5), 419-427. https://doi.org/10.1590/S0102-09352008000200022

Ítavo, L. C. V., Ítavo, C. C. B. F., Dias, A. M., Novais, M. F. S. M., Silva, F. F., Mateus, R. G., \& Schio, A. R. (2007a). Productive performance and economic evaluation of steers supplemented in the dry period in differed pastures, under two stoking rates. Revista Brasileira de Saúde e Produção Animal, 8(3), 229-238. http://revistas.ufba.br/index.php/rbspa/article/view/781/520

Lima, J. B. M. P., Rodríguez, N. M., Martha-Júnior, G. B., Guimarães-Junior, R., Vilela, L., Graça, D. S., \& Saliba, E. O. S. (2012). Supplementation of Nellore steers under grazing during the rainy/dry transition period. Arquivo Brasileiro de Medicina Veterinária e Zootecnia, 64(4), 943-952. https://doi.org/10.1590/S0102-09352012000400022

Ludke, C. B., Ciocca, J. R. P., Dandin, T. et al. (2012). Abate humanitário de bovinos. Rio de Janeiro:WSPA, 2012. 148

https://certifiedhumanebrasil.org/wp-content/uploads/2018/12/Programa-STEPS-\%E2\%80\% 93-Abate-Humanit\%C3\%A1rio-de-Bovinos.pdf

Mateus, R. G., Silva, F. F., Ítavo, L. C. V., Pires, A. V., Silva, R. R., \& Schio, A. R. (2011). Supplements for Nellore rearing in dry season: performance, intake and nutrient digestibility. Acta Scientiarum. Animal Sciences, $\quad 33(1), \quad$ 87-94. https://doi.org/10.4025/actascianimsci.v33i1.9100 
Minson, D. J. (1990). Forage in ruminant nutrition. San Diego: Academic Press, 1990. 483p.

Nagaraja, T. G., Newbold, C. J., van Nevel, C. J. \& Demeyer, D. I. (1997). Manipulation of ruminal fermentation. In: Hobson P.N., Stewart C.S. (eds). The Rumen Microbial Ecosystem. Springer, Dordrecht, 523-632. https://doi.org/10.1007/978-94-009-1453-7_13

National Research Council. (2000). Nutrient Requirements of Beef Cattle: Seventh Revised Edition: Update 2000. Washington, DC: The National Academies Press. https://doi.org/10.17226/9791

Prohmann, P. E. F., Branco, A. F., Paris, W., Cecato, U., Barreto, J. C., Oliveira, M. V. M, \& Goes, R. H. T. B. (2012a). Economic Evaluation of Supplementation and Yeast Culture Use for Beef Calves on Pasture. Revista Agrarian, 5(15), 61-67. http://ojs.ufgd.edu.br/index.php/agrarian/article/view/1369/1015

Prohmann, P. E., Branco, A. F., Paris, W., Barreto, J. C., Magalhaes, V. J., Goes, R. H. T. B., \& Oliveira, M. V. M. (2012b). Method of sampling and chemical characterization of forage intake by cattle in pasture ryegrass intercropping oats. Arquivo Brasileiro de Medicina Veterinária e Zootecnia, 64(4), 953-958. https://doi.org/10.1590/S0102-09352012000400023

Rangel, A. H. N., Leonel, F. P., Simplicio, A. A., \& Mendonça-Junior, A .F. (2008). Utilização de ionóforos na produção de ruminantes. Revista de Biologia e Ciências da Terra, 8(2), 173-182.

http://joaootavio.com.br/bioterra/workspace/uploads/artigos/19ruminantes-518170d0d1320.p df

Santos, S. A, Rotta, P. P., Costa e Silva, L. F., Menezes, A. C. B. Pina, D. S., \& Valadares Filho, S. C. (2016). Protein ruminal degradation of feeds and microbial protein synthesis. In: Valadares Filho, S. C., Costa E Silva, L. F., Lopes, S. A., Prados, L.F., Chizzotti, M.L., Machado, P.A.S., Bissaro, L.Z., Furtado, T. (eds). Cálculo de exigências nutricionais, formulação de dietas e predição de desempenho de zebuínos puros e cruzados. 2016. www.brcorte.com.br

Schio, A. R., Veloso, C. M., Silva, F. F., Ítavo, L. C. V., Mateus, R. G., \& Silva, R. R. (2011). Forage on offer for Nellore heifers supplemented during the drought and dry/rainy transition seasons. Acta Scientiarum. Animal Sciences, $33(1), \quad 9-17$. https://doi.org/10.4025/actascianimsci.v33i1.9112

Silva, F. F., Sá, J. F., Schio, A. R., Ítavo, L. C. V., Silva, R. R., \& Mateus, R. G. (2009). Suplementação a pasto: disponibilidade e qualidade $\mathrm{x}$ níveis de suplementação $\mathrm{x}$ desempenho. Revista Brasileira de Zootecnia, 38(1), 371-389. https://doi.org/10.1590/S1516-35982009001300037

Valadares Filho, S. C., Pina, D. S., Chizzotti, M. L., \& Valadares, R. F. D. (2010). Ruminal feed protein degradation and microbial protein synthesis. In: Valadares Filho, S.C., Marcondes, M.I., Chizzotti, M.L., Paulino, P.V.R. (eds). Exigências nutricionais de zebuínos puros e cruzados. 2 Ed. Viçosa, MG. UFV, DZO. 2010. https://v3.brcorte.com.br/bundles/junglebrcorte2/book/en/c2.pdf 


\section{Macrothink}

Journal of Agricultural Studies

ISSN 2166-0379 2020, Vol. 8, No. 2

Zervoudakis, J. T., Paulino, M. F., Cabral, L. S., Detmann, E., Valadares Filho, S. C., \& Kling de Moraes, E. H. B. (2008). Multiple supplements of self controlled intake for steers during the growing phase in the rainy season. Ciência e agrotecnologia, 32(6), 1968-1973. https://doi.org/10.1590/S1413-70542008000600041

\section{Copyright Disclaimer}

Copyright for this article is retained by the author(s), with first publication rights granted to the journal.

This is an open-access article distributed under the terms and conditions of the Creative Commons Attribution license (http://creativecommons.org/licenses/by/4.0/). 